\title{
THE EFFECTS OF ROLE STRESSORS AND EMOTIONAL SATISFACTION ON SERVICE QUALITY: MODERATING ROLE OF GENDER
}

\author{
Handrio Adhi Pradana \\ Management Department, Faculty of Economics \\ Universitas Islam Indonesia \\ e-mail: handrioadhip@gmail.com \\ Hunik Sri Runing Sawitri \\ Management Department, Faculty of Economics and Business \\ Universitas Sebelas Maret
}

\begin{abstract}
The objective of this research is to find out the effect of role ambiguity, role conflict, role overload, and work-family conflict on emotional satisfaction, the effect of emotional satisfaction on service quality, and gender moderation on the effect of emotional satisfaction on service quality. This research was conducted in Dr. Moewardi General Hospital. The research design used in was survey research. The population of this research was all nurses of Dr. Moewardi General Hospital. The sample consisted of 106 nurses taken using purposive sampling technique. The independent variables were role ambiguity, role conflict, role overload, work-family conflict, and emotional satisfaction. The dependent variables were service quality and emotional satisfaction, while gender was a moderating variable. Methods of analyzing data used in this research were multiple regression, simple regression, and subgroup analysis before which the instrument tests were conducted including validity and reliability tests. A multiple regression examined the effect of role ambiguity, role conflict, role overload, and work-family conflict on emotional satisfaction. Simple regression examined the effect of emotional satisfaction on service quality and subgroup analysis examined the moderation of gender on the effect of emotional satisfaction on the service quality. The result of this research showed that: (1) Role ambiguity, role overload, and work-family conflict affected the emotional satisfaction significantly and negatively while the role conflict did not affect significantly the emotional satisfaction, (2) The emotional satisfaction affected positively the service quality, (3) Gender did not moderate significantly the effect of emotional satisfaction on service quality.
\end{abstract}

Keywords: role stressors, emotional satisfaction, service quality, gender

\begin{abstract}
Abstrak
Tujuan penelitian ini adalah untuk menguji pengaruh role ambiguity, role conflict, role overload, dan work-family conflict pada kepuasan emosional, pengaruh kepuasan emosional pada kualitas pelayanan, dan moderasi gender terhadap pengaruh kepuasan emosional pada kualitas pelayanan. Penelitian ini dilakukan di RSUD Dr. Moewardi. Desain penelitian yang digunakan adalah penelitian survei. Populasi dalam penelitian ini adalah seluruh tenaga perawat RSUD Dr. Moewardi. Jumlah sampel sebanyak 106 perawat yang diambil secara purposive sampling. Variabel independen adalah role ambiguity, role conflict, role overload, work-family conflict, dan kepuasan emosional. Variabel dependen adalah kualitas pelayanan dan kepuasan emosional, sedangkan gender sebagai variabel moderasi. Metode analisis dalam penelitian ini menggunakan regresi berganda, regresi sederhana, dan analisis subgroup yang sebelumnya dilakukan uji instrumen, yaitu uji validitas dan reliabilitas. Regresi berganda menguji pengaruh role ambiguity, role conflict, role overload, dan work-family conflict pada kepuasan emosional. Regresi sederhana menguji pengaruh kepuasan emosional pada kualitas pelayanan dan analisis subgroup menguji moderasi gender terhadap pengaruh kepuasan emosional pada kualitas pelayanan. Hasil penelitian menunjukkan bahwa: (1) Role ambiguity, role overload, dan work-family conflict berpengaruh signifikan negatif pada kepuasan emosional sedangkan role conflict tidak signifikan mempengaruhi
\end{abstract}


kepuasan emosional, (2) Kepuasan emosional berpengaruh positif pada kualitas pelayanan, (3) Gender tidak signifikan memoderasi pengaruh kepuasan emosional pada kualitas pelayanan.

Kata kunci: role stressors, kepuasan emosional, kualitas pelayanan, gender

\section{INTRODUCTION}

Employee emotions is an essential element in the management of service quality. The role of emotions in the form of emotional satisfaction plays an important aspect of management that ultimately has implications for the quality of service expected. The relationship of emotional satisfaction and quality of service is then used as capital essential to the existence of an organization. Although the emotional satisfaction plays an important role in the quality of services, but an empirical study on the matter is still relatively small. Bagozzi, Gopinath, and Nyer (1999) suggested that more research is needed on emotions and their effect on employee behavior.

Based on the research of satisfaction, emotional satisfaction leads to the concept of a set of emotional responses obtained specifically through the experience commonly experienced (Westbrook \& Oliver, 1991). Typology generally accepted in the classification of emotions are emotions division into two parts, positive and negative emotions. Positive emotions include feelings of joy, pleasure and contentment. Negative emotions include feelings of anxiety, annoyance, anger, fear, depression, and disappointment (Bagozzi et al., 1999).

Over the last ten years, the study to the attention of the researchers, more interested in the field of quality of service (Nadiri \& Gunay, 2013). Today, the quality of service is regarded as a success factor affecting the competitiveness of an organization. Furthermore, the quality of service is also regarded as a decisive factor in order to make chance for the organization to differentiate itself from competitors and gain a sustainable competitive advantage (Gounaris, Stathakopoulos, \& Athanassopoulos, 2003).

According to $\mathrm{Lu}$, Shih, and Chen (2013), it is generally accepted in many industries is customer satisfaction depends on customer perceptions of the quality of service of employees. Therefore, we could conclude that a high quality of service which is the essence of the success of an organization. In addition, the business prospects of a company depends also on the company's ability to organize its internal activities such as increase employee satisfaction and generate high value-added services (Slatten, 2008).

Many studies in different industrial sectors, shows that service quality is an antecedent to behavioral intentions (Parasuraman, Zeithaml, \& Berry, 1985). Schneider and Bowen (1993) concluded that employee satisfaction is a significant predictor for quality of service. Schneider and Bowen (1993) have confirmed aphorisms that made founder Marriot hotel that "you can not make customers happy wth employees who are not happy". Lee, Lee and Lum (2008) concluded that the quality of service of employees positively influence on the level of organizational commitment of employees and negatively on the intention to quit. Research on the emotional satisfaction stating that the emotional satisfaction (positive and negative) have a significant effect on the quality of service of employees (Slatten, 2009). Slatten, Svensson, and Svaeri (2011) stated the quality of service of employees negatively influences intention to quit.

Slatten (2008) considered that the emotional satisfaction of an employee which is not met on the job can be caused by several things, namely role ambiguity (lack of clarity of direction and the absence of guidance), role conflict (conflict with co-workers, supervisors, and workgroups), role overload (the workload exceeds the capabilities), and work-family conflict (conflict between work and family responsibilities). Based on the theory of role, the demands of the role, and expectations regarding the performance termed the role stressors (Kahn, Wolfe, Quinn, Snoek, \& Rosenthal, 1964).

Rizzo, House, and Lirtzman (1970) stated, role ambiguity is described as a state of individuals who do not have clear guidelines on expectations for its role in the work or organization. Role conflict is seen as a mismatch in expectations pertaining to the role of perceived performance. Individuals who are at high levels of role ambiguity and role conflict, as the source of stress, will feel less satisfied with the job so as to lower the emotional saisfaction of employees (Yousef, 2002). 
Next, the cause of employees do not feel emotional satisfaction in his work is the role overload. Role overload can occur if: supervisors demanding more work than an employee than it should be (an employee can complete a good job at the time given), also when employees feel the demands of the job too much. In line with the implications of role ambiguity and role conflict, perceived workload exceeds the capacity of the individual causes of employees are dissatisfied with their work and ultimately lower the emotional satisfaction of employees.

The work-family conflict, Kahn et al. (1964) defines work-family conflict as a form of inter-role conflict, namely the pressure of work and family become incompatible with each other in some circumstances. Conflict of work appears to be a predictor of work-family conflict are more powerful than family conflicts, because most people have control work life less than control of his or her family life.

Based on the recommendation of Slatten (2008) regarding the focus on gender differences, the researcher add the variable of gender. In addition, Lutz (2007) has revealed that there are significant gender differences in job satisfaction variables. The focus on gender differences is undertaken with the hope to deepen the understanding of gender difference through its own investigation of gender-related differences in the effect of emotional satisfaction on the quality of service of employees (Slatten, 2008).

\section{LITERATURE REVIEW AND HYPO- THESES DEVELOPMENT}

\section{Emotional Satisfaction Effect on Service Quality}

Employees who are satisfied will do continuous quality improvement. Thus, the employee will act to provide a quality service. Several studies have shown that employees who are satisfied is the highest motivation to have a good moral at work and display performance more effective and efficient (Yoon and Suh, 2003).

On the other hand, Slatten (2008) stated that although the service of employees is recognized as an essential resource in the provision of a service, but few empirical studies that explicitly focus on the role of employee satisfaction on the quality of service. Cronin
(2003) recommends to conduct empirical studies of the effect of emotional dimension of satisfaction on the quality of service. Research on the emotional satisfaction stating that the emotional satisfaction (positive and negative) has significant effect on the quality of service of employees (Slatten, 2009).

H1: emotional satisfaction has positive effect on the quality of service of employees.

The Effects of Role Ambiguity, Role Conflict, and Role Overload on Emotional Satisfaction

Based on Singh, Verbeke, and Rhoads (1996), the three major stressors role that includes role ambiguity, role conflict, and role overload proven negative effect on the emotional satisfaction. Yousef (2002) has also been found that individuals who are at a high level of role ambiguity and role conflict, as the source of stress, will feel less satisfied with the work thus lowering the emotional satisfaction of employees.

In particular, for the role overload, Gibson (1992) has stated that excessive workloads can result in low self-esteem, decreased work motivation, and increased absenteeism. Furthermore, Slatten (2008) suggests that although there are no studies explicitly assess the effect of role overload on emotional satisfaction, but based on the definition and consequences of role overload, also on the Gibson's (1992) statement on implications of excessive workloads, it can be used to attract the hypothesis that role overload has negative effect on the emotional satisfaction.

$\mathrm{H} 2$ : role ambiguity has negative effect on the emotional satisfaction.

H3: role conflict has negative effect on the emotional satisfaction.

H4: role overload has negative effect on the emotional satisfaction.

\section{Work-Family Conflict Effect on Emotional Satisfaction}

The changing nature of work motivation and the general public has led both to the increasing number of single-parent households are larger and increasing the number of households that spousal career ambition is to pursue each other's work. These changes have increased the potential for conflict between the responsibilities of work and family responsibilities in all 
work environments (Slatten, 2008). Work and family life have mutual influence. Barling and MacEwen (1992) mentions the reciprocal influence as a spillover effect (unbalanced effect) from one field to another. However, labor relations consequences of work-family conflict can not be clearly defined.

Based on the type of work-family conflict, namely strain-based conflict, there are indicators that show the work-family conflict negatively affected satisfaction because strainbased conflict occurs when the pressure of one's role affect the performance of other roles. For example, very difficult for a person able to work wholeheartedly when the pressing family problems him or herself (Elloy \& Smith, 2003).

H5: work-family conflict negatively affect the emotional satisfaction.

\section{The Moderating Role of Gender in the Rela- tionship between Emotional Satisfaction and Service Quality}

There are differences in job satisfaction between men and women in the work environment, so that the motivation and specific programs for workers required in this case (Olorunsola, 2010). Several empirical studies have found gender differences in the effects of job satisfaction (Lutz, 2007). Based on the investigation of the influence of gender differences in satisfaction construct, Slatten (2008) suggest focusing on gender differences in the effects of emotional satisfaction on the quality of service that aims to deepen the understanding of gender differences in the context of emotional satisfaction in the quality of service.

H6: gender moderates the effect of emotional satisfaction on the quality of service.

\section{RESEARCH METHODS}

\section{Sampe and Procedure}

In this study, information was collected from respondents through questionnaire conducted on nurses of Hospital of Dr. Moewardi. The sampling technique used is purposive criteria of nurses who are married and have minimum working term of one year.

\section{Measurements}

Role ambiguity is the condition of the nurses who feel the work does not have clear guide- lines and objectives and measured by 6 item questionnaire developed by Rizzo et al. (1970).

Role conflict is a condition of nurses who experience conflict at work, either with colleagues, supervisors, or in workgroups and measured with 8 item questionnaire developed by Rizzo et al. (1970).

Role overload is that the working conditions of nurses required to do work beyond its ability and measured with 9 item questionnaire developed by Caplan (1971).

Work-family conflict is a condition of nurses who experienced the conflict between the demands of work and family responsibilities and measured by 5 item questionnaire developed by Netemeyer, Boles, and McMurrian (1996).

Emotional satisfaction is the emotional state of the nurses who showed a sense of like or dislike towards cognitive assessment of the work environment and measured with 4 item questionnaire proposed by Reynolds and Beatty (1999).

Service quality is how well nurses provide a service to be able to meet or even exceed the expectations of service users (patients) and measured with 4 item questionnaire developed by Dabholkar, Shepherd, and Thorpe (2000).

The moderating gender is the term for the biological condition of a person, male and female. Gender is a variable dischotomous coded. Variables with code 0 for men and 1 for women.

\section{Analysis}

Testing instrument is done with validity and reliability test. Validity test using CFA (Confirmatory Factor Analysis) technique with the help of the software SPSS 16.0 for Windows. Tolerance limits loading factor was 0.4 with the provisions of qualifying criteria KMO (KaiserMeyer-Olkin) and Barlett's Test over 0.5 and significant at 0.05 . Then, coefficient Anti Image Matrices which indicates the adequacy of the sample size that can be obtained for further analysis is at least 0.5 . Reliability test using Cronbach's Alpha technique with minimum acceptance value is 0.6 .

In this study, to test the effect of independent variables on the dependent variables used multiple regression analysis and simple regression. Then, the moderating effects of 
gender performed by sub-group regression analysis. Testing of this regression analysis using the software SPSS 16.0 for Windows.

\section{RESULTS}

\section{Testing Validity}

The table is the end result after the previous CFA testing, there are several items that are not valid statements that should be reduced/removed. Table 1 shows the results ex- tracted perfectly and has a loading factor $\geq 0.40$ so that all items used to express each variable is declared valid.

\section{Testing Reliability}

Reliability testing results in Table 2 that each of the variables studied had Cronbach's alpha values $>0.60$, which means all of the instruments in this study has been reliable.

Table 1: Validity Output

\begin{tabular}{|c|c|c|c|c|c|c|c|}
\hline \multirow{2}{*}{ Variable } & \multirow{2}{*}{ Items } & \multicolumn{6}{|c|}{ Factors } \\
\hline & & 1 & 2 & 3 & 4 & 5 & 6 \\
\hline \multirow{6}{*}{ Role Ambiguity } & RA1 & & & & .402 & & \\
\hline & RA2 & & & & .685 & & \\
\hline & RA3 & & & & .785 & & \\
\hline & RA4 & & & & .804 & & \\
\hline & RA5 & & & & .752 & & \\
\hline & RA6 & & & & .818 & & \\
\hline \multirow{6}{*}{ Role Conflict } & $\mathrm{RC} 3$ & .679 & & & & & \\
\hline & $\mathrm{RC} 4$ & .806 & & & & & \\
\hline & $\mathrm{RC} 5$ & .681 & & & & & \\
\hline & RC6 & .510 & & & & & \\
\hline & $\mathrm{RC7}$ & .771 & & & & & \\
\hline & $\mathrm{RC} 8$ & .665 & & & & & \\
\hline \multirow{7}{*}{ Role Overload } & RO1 & & & & & & .486 \\
\hline & RO3 & & & & & & .547 \\
\hline & RO5 & & & & & & .617 \\
\hline & RO6 & & & & & & .453 \\
\hline & RO7 & & & & & & .438 \\
\hline & RO8 & & & & & & .522 \\
\hline & RO9 & & & & & & .716 \\
\hline \multirow{4}{*}{ Work-Family Conflict } & WFC1 & & & .781 & & & \\
\hline & WFC2 & & & .765 & & & \\
\hline & WFC3 & & & .823 & & & \\
\hline & WFC4 & & & .675 & & & \\
\hline \multirow{4}{*}{ Emotional Satisfaction } & KE1 & & & & & .826 & \\
\hline & KE2 & & & & & .774 & \\
\hline & KE3 & & & & & .622 & \\
\hline & KE4 & & & & & .735 & \\
\hline \multirow{4}{*}{ Service Quality } & KP1 & & .789 & & & & \\
\hline & KP2 & & .847 & & & & \\
\hline & KP3 & & .811 & & & & \\
\hline & KP4 & & .872 & & & & \\
\hline
\end{tabular}

Source: primary data which are processed

Table 2. Reliability Output

\begin{tabular}{lcc}
\hline \multicolumn{1}{c}{ Variable } & Cronbach's Alpha & Information \\
\hline Role Ambiguity & 0,853 & Good \\
Role Conflict & 0,836 & Good \\
Role Overload & 0,727 & Accepted \\
Work-Family Conflict & 0,865 & Good \\
Emotional Satisfaction & 0,898 & Good \\
Service Quality & 0,895 & Good \\
\hline
\end{tabular}

Source: primary data which are processed 


\section{Results of Hypotheses Testing}

\section{Role Stressors Effect on Emotional Satisfaction}

Table 3: Result of Multiple Regression Analysis

\begin{tabular}{cccc}
\hline Variable & Standardized $\beta$ & $\mathrm{t}$ & Sig. \\
\hline Konstanta & & 16.058 & .000 \\
RA & -.284 & 3.461 & .001 \\
RC & .138 & 1.487 & .140 \\
RO & -.180 & -2.060 & .042 \\
WFC & -.476 & -5.328 & .000 \\
\hline
\end{tabular}

Source: primary data which are processed

Table 3 shows that all variables of role stressors supported except on the variable role conflict because the $p$-value $>0.5$. $\mathrm{R}^{2}$ value of role stressors effect on the emotional satisfaction showed an adjusted $\mathrm{R}^{2}$ of 0.373 . This means that $37.3 \%$ of dependent variable (emotional satisfaction) that can be explained by the independent variable (role ambiguity, role conflict, role overload, and work-family conflict), while the remaining $\left(1-\mathrm{R}^{2}\right)$, ie $62.7 \%$ explained by other causes outside the model.

\section{Emotional Satisfaction Effect on Service Quality}

Table 4: Result of Simple Regression Analysis

\begin{tabular}{cccc}
\hline Variable & Standardized $\beta$ & $\mathrm{t}$ & Sig. \\
\hline Konstanta & & 9.214 & .000 \\
KE & .404 & 4.503 & .000 \\
\hline
\end{tabular}

Source: primary data which are processed

Table 4 shows that the emotional satisfaction has significant positive effect on the quality of service of $\mathrm{p}$-value $<0.5 . \mathrm{R}^{2}$ the emotional satisfaction on the quality of services showed an adjusted $R^{2}$ of 0.155 . This means that $15.5 \%$ of dependent variable (quality of service) which can be explained by the independent variable (emotional satisfaction), while the remaining $\left(1-R^{2}\right)$, ie $84.5 \%$ explained by other causes beyond the model.

The Moderating Role of Gender in the Relatioship between Emotional Satisfaction and Service Quality

Table 5: Result of Subgroup Analysis

\begin{tabular}{llccc}
\multicolumn{1}{c}{ Model } & Standardized $\beta$ & $\mathrm{t}$ & Sig. \\
\hline 1. Konstanta & & 7.706 & .000 \\
KEpa/KE0 & .120 & .661 & .514 \\
2. Konstanta & & 9.990 & .000 \\
KEpi/KE1 & .063 & .536 & .593 \\
\hline
\end{tabular}

Source: primary data which are processed
Table 5 shows that KEpa $t$ value of 0.661 with probability of 0.514 at significant level $\alpha=5 \%$, so it can be said that emotional satisfaction respondents men had no significant effect on the quality of service. Likewise, KEpi t value of 0.536 with probability of 0.593 at significant level $\alpha=5 \%$, so the emotional satisfaction of respondent women also had no significant effect on the quality of service.

Based on the analysis, testing two models was insignificant all of them, so both $\beta$ do not need to be tested and it can be concluded that gender did not moderate the influence of emotional satisfaction on the quality of service.

\section{DISCUSSION}

\section{Emotional Satisfaction Effect on Service Quality}

The analysis showed that the emotional satisfaction has positive significant effect on the quality of service. The higher positive influence of emotional satisfaction, service quality is also increasing, conversely the lower the emotional satisfaction the quality of service will also be decreased. According to the respondents, it appears that nurses have high emotional satisfaction and service quality in their work.

These results support Slatten (2008) which states that employees who feel satisfied emotionally will display a higher quality of service than employees who are not satisfied.

\section{Role Ambiguity Effect on Emotional Satis- faction}

Results showed that role ambiguity has significant negative effect on the emotional satisfaction. The higher negative influence of role ambiguity, emotional satisfaction even more decreased, whereas the lower the role ambiguity, the emotional satisfaction will increase. This negative effect also appears on the responses regarding role ambiguity and emotional satisfaction that nurses experiencing role ambiguity are low, while high emotional satisfaction.

These results are at odds with Slatten (2008) found that role ambiguity does not significantly affect the emotional satisfaction. Differences in the results of this analysis is made possible by several things, namely the length of working life and job descriptions of each object in the research. 


\section{Role Conflict Effect on Emotional Satisfac- tion}

Based on the analysis in Table 3 , the value of $\beta$ of 0,138 did not significantly affect the emotional satisfaction because $\mathrm{p}>0.05$, it can be concluded H3 is not supported. This could be because the respondents did not feel significant conflict in his or her role as a nurse. Response regarding the role conflict, it appears that the nurses feel low role conflict in their work place. Response about emotional satisfaction, it appears that the nurses feel emotional satisfaction are relatively high.

\section{Role Overload Effect on Emotional Satisfac- tion}

Results indicate that role overload has significant negative effect on the emotional satisfaction. The higher negative influence of role overload, emotional satisfaction even more decreased, whereas the lower the role overload the emotional satisfaction will increase. This negative effect also appears on the responses regarding role overload and emotional satisfaction that nurses have low role overload while high emotional satisfaction.

\section{Work-Family Conflict Effect on Emotional Satisfaction}

The analysis showed that work-family conflict has significant negative effect on emotional satisfaction. The higher negative influence of work-family conflict, emotional satisfaction even more decreased, whereas the lower workfamily conflict, the emotional satisfaction will increase. This negative effect also appears on respondents experience about the work-family conflict and emotional satisfaction that nurses have low work-family conflict while high emotional satisfaction.

\section{The Moderating Role of Gender in the Rela- tionship between Emotional Satisfaction and Service Quality}

The influence of emotional satisfaction in the service quality are not severely affected by gender. This means emotional satisfaction among respondents of men and women there is no higher or lower in the display service quality or it can be said that the emotional satisfaction respondents men and women alike in realizing service quality. This statement is in accordance with the first hypothesis stating supports positive significant effect emotional satisfaction on service quality.

\section{CONCLUSIONS, LIMITATIONS, AND FUTURE DIRECTIONS}

Based on the results of hypothesis testing performed by multiple regression, simple regression, and subgroup analyzes showed that the service quality is significantly affected by the emotional satisfaction while the emotional satisfaction is influenced significantly by role ambiguity, role overload and work-family conflict. Meanwhile, role conflict does not significantly affect the perceived emotional satisfaction of nurses and gender did not significantly moderate the influence of emotional satisfaction on service quality.

However, this study is not without faults: (1) The study was conducted at Hospital Dr. Moewardi and just take nurses as respondent, so the generalizability of this study is limited to nurses Hospital Dr. Moewardi, (2) This study focuses on the general effects of emotional satisfaction on service quality and does not specify the dimensions of the construct of emotional satisfaction, (3) This study only focused on the antecedents and influences emotional satisfaction from the perspective of employees, so it is not identified sources of emotional satisfaction and service quality as a whole as well as the perspectives of others.

As the improvement of quality in order to develop the topics of research in the same field, the researchers can consider the following: (1) Further research is expected to be replicated and expanded generalization of the findings to date by using samples from various sectors, such as public services other than hospital, industry, and other government and private sector, (2) Future studies can determine the more exact dimensions of emotional satisfaction specific that is the best predictor for service quality, (3) Future studies are expected to focus on other perspectives besides employees in identify the sources of emotional satisfaction and service quality. Kennedy-McDoll and Anderson (2002) stated that there has been no research to develop model of leadership style and emotion as a mediator for the performance. An exploratory study on the influence of leadership 
style on emotional satisfaction and service quality will be research that is useful and necessary in the future (Slatten, 2008).

\section{REFERENCES}

Bagozzi, R.P., Gopinath, M. and Nyer, P.U. 1999. The role of emotions in marketing, Journal of the Academy of Marketing Science, Vol. 27 No. 2, pp. 184206.

Barling, J. and MacEwen, K.E. 1992. Linking work experiences to facets of marital functioning, Journal of Organizational Behavior, Vol. 13, pp. 573-583.

Cronin, J.J. 2003. Looking back to see forward in services marketing: some ideas to consider, Managing Service Quality, Vol. 13 No. 5, pp. 332-337.

Elloy, D.F. and Smith, C.R. 2003. Patterns of Stress, Work-Family Conflict, Role Conflict, Role Ambiguity and Overload Among Dual-Career and Single-Career Couples: An Australian Study, Cross Cultural Management, Vol. 10 No. 1, pp. 55-66.

Gibson R., Ivancevich L. and Donnely, R. 1992. Organizations: Behaviour, Structure, Process, Irwin Inc.

Gounaris, S.P., Stathakopoulos, V. and Athanassopoulos, A.D. 2003. Antecedents to perceived service quality: an exploratory study in the banking industry, International Journal of Bank Marketing, Vol. 21 No. 4, pp. 168-190.

Kahn, R.L., Wolfe, D.M., Quinn, R.P., Snoek, J.D. and Rosenthal, R.A. 1964. Organizational Stress: Studies in Role Conflict and Ambiguity, Wiley, New York, NY.

Kennedy-McDoll, J.R. and Anderson, R.D. 2002. Impact of leadership style and emotions on subordinate performance. The Leadership Quarterly, Vol. 13, pp. 545-59.

Lee, S.H., Lee, T.W. and Lum, C.F. 2008. The effects of employee services on organizational commitment and intentions to quit, Personnel Review, Vol. 37 No. 2, pp. 222-237.

Lu, C., Shih, Y., \& Chen, Y. 2013. Effects of emotional labor and job satisfaction on oganizational citizenship behaviors: A case study on business hotel chains. International Journal of Organizational Innovation, Vol.5 No.4, pp. 165-176.

Lutz, C.K. 2007. Gender-job satisfaction differences across Europe: An indicator for labour market modernization, International Journal of Manpower, Vol. 28 No. 1, pp. 75-94.

Nadiri, H. and Gunay, G. N. 2013. An empirical study to diagnose the outcomes of customers' experiences in trendy coffee shop. Journal of Business Economics and Management, Vol. 14 No. 1, pp. 22-53.

Olorunsola, E.O. 2010. Job Satisfaction and Gender Factor of Administrative Staff in South West Nigeria Universities, Contemporary Issues in Education Research, Vol. 3 No. 10, pp. 51-55.

Parasuraman, A., Zeithaml, V.A. and Berry, L.L. 1985. A Conceptual Model of Service Quality and Its Implications for Future Research, The Journal of Marketing, Vol. 49 No. 4, pp. 41-50.

Rizzo, J.R., House, R.J. and Lirtzman, S.I. 1970. Role conflict and ambiguity in complex organizations, Administrative Science Quarterly, Vol. 15 No. 2, pp. 150-63.

Schneider, B. and Bowen, D.E. 1993. The service organization: human resources management is crucial, Organizational Dynamics, Vol. 21 No. 4, pp. 39-52.

Singh, J., Verbeke, W. and Rhoads, G.K. 1996. Do Organizational Practices Matter in Role Stress Processes? A study of Direct and Moderating Effects for Marketing-Oriented Boundary Spanners, Journal of Marketing, Vol. 60, pp. 6986.

Slatten, T. 2008. Antecedents and effects of emotional satisfaction on employeeperceived service quality, Managing 
Service Quality, Vol. 18 No. 4, pp. 370-386.

Slatten, T. 2009. The effects of managerial practice on employee-perceived service quality: The role of emotional satisfaction, Managing Service Quality, Vol. 19 No. 4, pp. 431-455.

Slatten, T., Svensson, G. and Svaeri, S. 2011. Service quality and turnover intentions as perceived by employees: Antecedents and consequences, Personnel Review, Vol. 40 No. 2, pp. 205-221.

Westbrook, R.A. and Oliver, R.L. 1991. The Dimensionality of Consumption Emotion Patterns and Consumer Satisfac- tion, Journal of Consumer Research, Vol. 18 No. 1, pp. 84-91.

Yoon, M.H. and Suh, J. 2003. Organizational citizenship behaviours and service quality as external effectiveness of contact employees. Journal of Business Research, Vol. 56 No. 8, pp. 597-611.

Yousef, D.A. 2002. Job satisfaction as a mediator of the relationship between role stressors and organizational commitment: A study from an Arabic cultural perspective, Journal of Managerial Psychology, Vol. 17 No. 4, pp. 250266. 